\title{
PARAGENESES OF FRACTURES IN LARGE FAULT ZONES OF WEST TRANSBAIKALIA
}

\author{
A. V. Cheremnykh \\ Institute of the Earth's Crust, Siberian Branch of RAS, Irkutsk, Russia
}

\begin{abstract}
Our study was focused on the parageneses of heterogeneous fractures in the large fault zones of West Transbaikalia, Russia. We reconstructed the latest deformation in the fault zones of Transbaikalia, within which paleoseismic dislocations are known and M 4.7 earthquakes take place. To obtain statistically justified solutions on the kinematic types of the largest faults of West Transbaikalia, we collected the required data and conducted the structural and paragenetic analysis of the fractures in the study area. In the Chikoi-Ingoda, Khilok, North Tugnui and North Zagan fault zones, we created a network of 54 observation points and measured more than 5500 details of local fractures and faults. Recorded were the observed slickensides, the displacements of markers, and other details of rock fracturing. Based on the analysis results, we calculated a ratio of heterochronous dynamic settings for formation of the observed fault group. It shows that NW-SE-trending extension and compression are dominant in the study region. The parageneses of E-NE-striking faults, i.e. regional faults longitudinal to the depressions of West Transbaikalia, are abundant in the studied fault zones and generally observed in heterochronous formations, including the Cenozoic sediments. This fact, along with the focal mechanisms of the recently recorded earthquakes, suggests that these faults are young. Besides, in the Tugnui basin and the area southeast of the Chikoy depression, the right-lateral strike-slip setting was reconstructed for E-NE-trending faults. Our study pioneers in the quantitative analysis of the fault parageneses of West Transbaikalia. Considering the development of the network of large faults in the study area, we reconstructed the main stages and the kinematic types of the second-order fractures that constitute the internal structure of the studied fault zones at each stage of their tectonic development.
\end{abstract}

Key words: West Transbaikalia; local fracture; regional fault; structural parageneses; earthquake; normal fault; analysis by ranks

\section{RESEARCH ARTICLE}

Received: February 21, 2018

Handling Editor: K.Zh. Seminsky 


\title{
ПАРАГЕНЕЗЫ РАЗРЫВОВ В КРУПНЫХ РАЗЛОМНЫХ ЗОНАХ ЗАПАДНОГО ЗАБАЙКАЛЬЯ
}

\section{А. В. Черемных}

\author{
Институт земной коры СО РАН, Иркутск, Россия
}

\begin{abstract}
Аннотация: Приводятся результаты изучения парагенезов разноранговых разрывов в зонах крупных дизъюнктивов Западного Забайкалья. Актуальность исследования связана с необходимостью реконструкции наиболее поздних деформаций в зонах разломов Забайкалья, в пределах которых известны палеосейсмодислокации и в настоящее время происходят землетрясения с магнитудой 4.7. Для получения статистически обоснованного решения о кинематическом типе наиболее крупных разломов Западного Забайкалья был собран необходимый фактический материал, на основе которого проведен структурно-парагенетический анализ разрывов и трещиноватости горных пород. Для зон Чикой-Ингодинского, Хилокского, Северо-Тугнуйского и Северо-Заганского дизъюнктивов создана сеть из 54 точек наблюдения, на которых измерено более 5500 элементов залегания локальных разрывов и трещин, задокументированы штрихи скольжения, смещения маркеров и другие проявления разрывных деформаций породного массива. Проведенный анализ позволил установить соотношение разновозрастных динамических обстановок формирования парагенезов изученных разломных зон, главными из которых по мере встречаемости являются растяжение и сжатие по направлению северо-запад - юго-восток. Парагенезы сбросов восток-северо-восточного простирания - региональных разломов, продольных по отношению ко впадинам Западного Забайкалья, - широко распространены в изученных разломных зонах и характерны для разновозрастных образований, в том числе для кайнозойских осадков, что наряду с механизмами очагов недавно произошедших землетрясений свидетельствует о молодом возрасте их формирования. Кроме того, в пределах Тугнуйской впадины и к юго-востоку от Чикойской депрессии реконструированы обстановки правостороннего сдвига для разломов восток-северовосточной ориентировки. Впервые на количественной основе изучены парагенезы разломов Западного Забайкалья, реконструированы главные этапы развития сети крупных разломов территории, а также кинематический тип систем разрывов 2-го порядка, составляющих внутреннюю структуру изученных дизъюнктивов на каждом из этапов их тектонического развития.
\end{abstract}

Ключевые слова: Западное Забайкалье; локальный разрыв; региональный разлом; структурный парагенез; землетрясение; сброс; ранговый анализ

\section{1. ВВЕДЕНИЕ}

Крупные разломы земной коры характеризуются длительной историей развития, в ходе которой на фоне изменяющейся во времени ориентировки полей напряжений меняются и знаки подвижек по разломам при консервативности их сети [Sherman, 1977]. При этом трансформируется внутренняя структура разломных зон, рисунок которой (сеть разрывов второго порядка) зависит от характера перемещения крыльев дизъюнктива. На специфике пространственной позиции разрывов второго порядка в пределах зоны дизъюнктива первого порядка основаны реконструкции условий формирования разломных зон структурно-парагенетическими методами. Парагенез разрывов зон скалывания охарактеризован в многочисленных работах, базирующихся на результатах геолого-структурных и экспериментальных исследований разноранговых дизъюнктивов [Lukianov, 1965; Gzovsky,
1975; Stoyanov, 1977; Sherman, Pleshanov, 1980; Rastsvetaev, 1982; Hancock, 1985; Seminsky, 2003, 2014, 2015; и дp.]. Парагенетические методы позволяют выявить устойчивые ассоциации исследуемых структур и реконструировать обстановки их формирования.

Актуальность изучения разноранговых разломов Западного Забайкалья обусловлена тем, что для района известны палеосейсмичность [Smekalin et al., 2010], а также исторические и современные землетрясения [Radziminovich, 2014; Melnikova et al., 2016, 2017]. Однако тектонические модели кинематики крупных разломов на поздних этапах развития региона еще недостаточно разработаны, так как основная сейсмотектоническая активность фиксируется к западу от рассматриваемого района, где для зоны субширотного Болнайского (Хангайского) разлома характерны левосторонние сдвиговые перемещения [Jolivet et al., 2013; Arzhannikova et al., 2015; и др.]. 
Обобщение сведений о наиболее крупных разломах Забайкалья приведено в работе сотрудников Геологического института СО РАН (г. Улан-Удэ), в которой разломные зоны охарактеризованы как объемные геологические тела, внутренняя структура которых состоит из различно ориентированных мелких разрывов [Volkov, 1978]. В монографии высказывается мысль о том, что для глубинных разломов Забайкалья сложно выявить определяющий морфолого-генетический тип, хотя и отмечается преобладание сбросов. Кинематические типы крупных разломов региона, таких как Чикой-Ингодинский, Хилокский и Тугнуй-Кондинский, формирующих зону Монголо-Охотского шва, на разных тектонических этапах развития региона рассмотрены в статье [Demin et al., 1982]. В этой работе главное внимание уделено ранним этапам формирования Монголо-Охотского шва. Вместе с тем наибольший интерес представляют молодые разрывные деформации, связанные с мезозойской активизацией и кайнозойским этапом развития региона.

Перед нашим исследованием стояла задача изучения парагенезов разрывов разного ранга в пределах зон известных крупных разломов Западного Забайкалья с целью установления их типов, характерных для молодых тектонических этапов. Для этого изучались разрывы и трещины, образовавшиеся, согласно С.И. Шерману [Sherman, 1977], при хрупком и квазихрупком разрушении верхней части земной коры в зонах крупных разломов. Для получения статистически обоснованного решения о кинематических типах разломов Западного Забайкалья в пределах их зон был собран необходимый фактический материал, на основе которого проведен структурно-парагенетический анализ разрывов и трещиноватости горных пород.

\section{2. ФАКТИЧЕСКИЙ МАТЕРИАЛ И МЕТОДЫ ИССЛЕДОВАНИЯ}

Необходимый для проведения исследования фактический материал был собран в окрестностях Тугнуйской, Малетинской и Чикойской впадин, что позволило создать достаточную для анализа сеть точек наблюдения в зонах Северо-Тугнуйского, Северо-Заганского, Хилокского и Чикой-Ингодинского разломов (рис. 1). Массовые замеры разрывов и трещиноватости собраны в разновозрастных породах, в том числе сформированных в мезозойское и кайнозойское время (рис. $2, a$, б). В преобладающем большинстве изучались неминерализованные разрывы, а также отдельные трещины или дислокации, на поверхности которых наблюдались низкотемпературные минералы, образующиеся в приповерхностных условиях (рис. 2, в). На некоторых точках наблюдения кинематический тип локаль- ных разрывов дополнительно был установлен при изучении специфических структурных форм, таких как борозды и штрихи скольжения (рис. 2, 2), а также смещения маркеров. Маркерами, как правило, были границы галек в мезозойских и кайнозойских конгломератах и галечниках. Возможность применения многих известных методов структурного анализа при изучении трещиноватости в грубообломочных отложениях показана в работе [Gladkov, Lunina, 2004].

Первичная обработка замеров трещиноватости горных пород проведена с использованием компьютерной программы «Структура», которая создана в лаборатории тектонофизики Института земной коры СО РАН (г. Иркутск). В ней реализованы алгоритмы построения структурных диаграмм в стереографических проекциях, выделения систем трещин по результатам расчета их плотности, а также известные тектонофизические методы реконструкции осей тектонических напряжений и векторы смещения по разлому [Gzovsky, 1975; Parfenov, 1984; Danilovich, 1961]. Штрихи скольжения на поверхностях трещин и смещения маркеров, зафиксированные в пределах некоторых коренных выходов, а также выявленные на диаграммах пояса трещин использовались для верификации результатов парагенетического анализа.

Для определения кинематического типа региональных разломов Западного Забайкалья было применено специальное картирование разломных зон, базирующееся на парагенетическом анализе массовых замеров повсеместно распространенной трещиноватости горных пород. Данный подход недавно получил полную методическую завершенность и в настоящее время является наиболее эффективным способом исследования разломной структуры земной коры с учетом ее ранговой соподчиненности [Seminsky, 2014, 2015]. Он позволяет: 1) выявить разнообразные локальные разрывы в пределах крупной (региональной) разломной зоны; 2) на основе ранжирования локальных разрывов различных кинематических типов установить морфолого-генетические типы более крупных разломов; 3) реконструировать обстановки, в которых развивались эти разломы на разных этапах тектонической активности в регионе.

В основе метода лежит понятие о структурном парагенезе разлома как совокупности систем разрывов (2-го порядка), образовавшихся в одной динамической обстановке (поле напряжений 1-го порядка) и составляющих в плане единый линейно вытянутый участок земной коры [Seminsky, 2014]. На разных этапах анализа используются трафареты, представляющие собой идеализированные сети трещин и разрывов в разломных зонах разного морфогенетического типа (рис. 3). Трафареты, раз- 


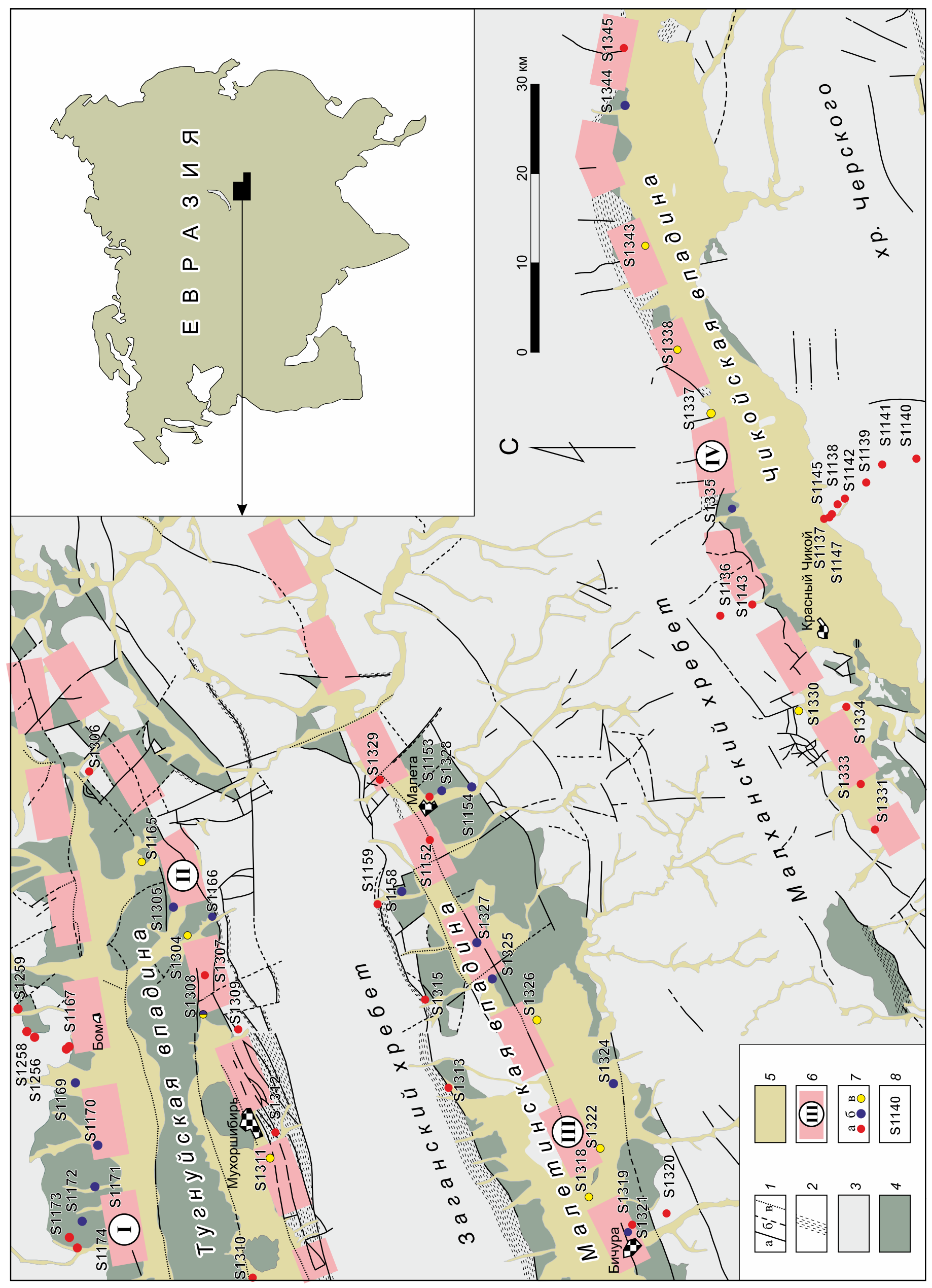


Рис. 1. Схема разломов района исследования и положение точек сбора фактического материала для проведения анализа.

1-5 - некоторые особенности геологической структуры согласно [Naletov, 1959, 1963; Shcheglov, 1961; Starchenko, 1962; Florensov, 1964]: 1 - разломы (а - достоверные, б - предполагаемые, в - перекрытые осадками), 2 - зоны тектонитов (катаклаза, рассланцевания, милонитизации), 3 - разновозрастные магматические образования и домезозойские метаморфические породы, 4 - мезозойские отложения, 5 - кайнозойские отложения; 6 - осевые линии крупных разломов (цифры в кружках): I - СевероТугнуйского, II - Северо-Заганского, III - Хилокского, IV - Чикой-Ингодинского; 7 - точки геолого-структурных наблюдений (а в магматических породах, б - в вулканогенно-осадочных породах мезозойского возраста, в - в кайнозойских отложениях); 8 номера точек

Fig. 1. Schematic fault map of the study area. The map shows the locations of the observation points.

1-5 - features of the geological structure according to [Naletov, 1959, 1963; Shcheglov, 1961; Starchenko, 1962; Florensov, 1964]: 1 - faults (a - observed, 6 - assumed, B - covered by sediments), 2 - zones of tectonites (cataclase, schistosity, mylonitization), 3 - hererochronous mafic formations and pre-Mesozoic metamorphic rocks, 4 - Mesozoic deposits, 5 - Cenozoic deposits; 6 - axial lines of major faults. Fault numbers in circles: I - North Tugnui, II - North Zagan, III - Khilok, IV - Chikoi-Ingoda; 7 - points of geological structural observations in: a - magmatic rocks, $\sigma$ - Mesozoic volcanogenic-sedimentary rocks, B - Cenozoic deposits; 8 - numbers of the observation points.

работанные для выявления разрывов локального уровня, учитывают наиболее полный парагенез структурных элементов, который состоит из разрыва первого порядка - сместителя, разрывов второго порядка и сопряженных с ними трещин второстепенной и дополнительной систем (рис. $3, a$ ). Сопоставление путем наложения трафаретов на структурные диаграммы трещиноватости позволяет по принципу совпадения максимумов плотности трещин и полюсов структурных элементов парагенеза установить наиболее вероятный тип локального разрыва. При этом объясняется положение не только сопряженной пары или тройки систем трещин, но и других максимумов структурной диаграммы. Парагенетический анализ локальных разрывов в зоне более крупного разлома проводится с использованием трафаретов, на которых отображены только координаты полюсов разрывов (рис. $3,6)$. При анализе на этом этапе значимым является не только совпадение положения полюса разрыва, но и, что более важно, его кинематического типа. В целом, методу свойственно [Seminsky, 2015]: 1) единообразие наблюдений в каждой точке; 2) статистический характер анализа данных; 3) высокая степень формализации основных операций; 4) парагенетический, ранговый и эволюционный принципы анализа материала на каждом этапе.

Особенности сбора и обработки фактического материала на первом этапе структурно-парагенетического анализа трещиноватости и разрывов детально изложены в работе [Burzunova, 2017]. В нашей статье большее внимание уделено ранжированию разрывных парагенезов и выявлению этапов формирования разломных зон. Исследования выполнены на основе методических приемов [Seminsky, Cheremnykh, 2011; Seminsky, 2015], которые в статье подробно рассмотрены при описании полученных результатов.

\section{3. РЕЗУЛЬТАТЫ ИССЛЕДОВАНИЯ}

Этапы проведения и результаты порангового структурно-парагенетического анализа дизъюнктивов с целью установления различных динамических обстановок их формирования рассмотрим последовательно для каждого из крупных разломов Западного Забайкалья. Это соответствует определению парагенеза разлома как совокупности систем разрывов, образовавшихся в одной динамической обстановке и пространственно приуроченных к линейно вытянутому участку земной коры [Seminsky, 2014].

В Чикой-Ингодинской разломной зоне, на протяжении 113 км по ее простиранию, произведены геолого-структурные наблюдения в 15 выходах горных пород (см. рис. 1). Именно здесь, у подножия юго-восточного склона Малханского хребта, зафиксирован разлом, активный в плиоцен-четвертичное время [Lunina, 2016], на примере которого рассмотрим общую последовательность проведения порангового структурно-парагенетического анализа.

На рисунке 4 приведена схема этапов анализа, проведенного для этого дизъюнктива. Первый этап - обработка диаграмм трещиноватости и разрывов в отдельных точках (рис. 4, a) - позволил получить 17 решений о кинематическом типе локальных разрывов. Затем была проведена систематизация полученных решений путем составления и анализа роза-диаграммы азимутов простирания разрывов (рис. 4, б). На роза-диаграмме обособились семь направлений разрывов, однако северо-западные и субмеридиональные разрывы, немногочисленные и ортогональные более значимым направлениям 50-60 и 80, вероятнее всего, являются элементами парагенезов региональных разломов северовосточного и восток-северо-восточного простира- 


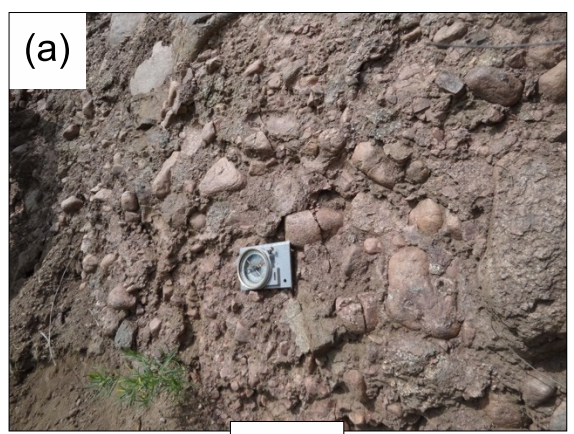

$\mathrm{S} 1308$
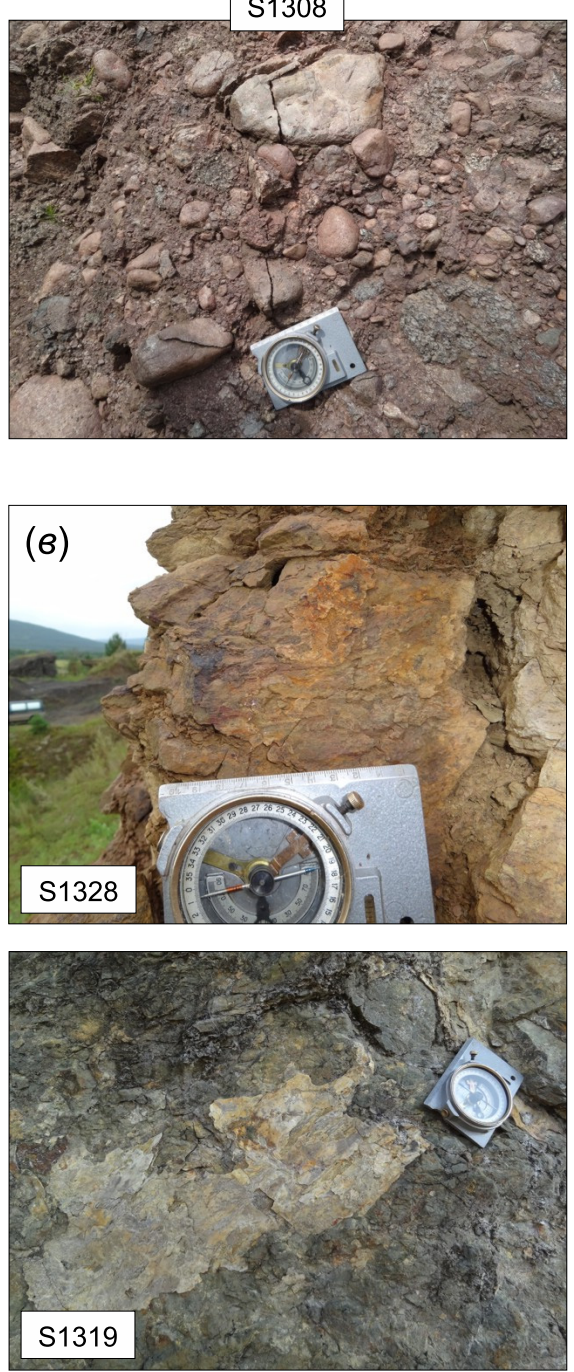

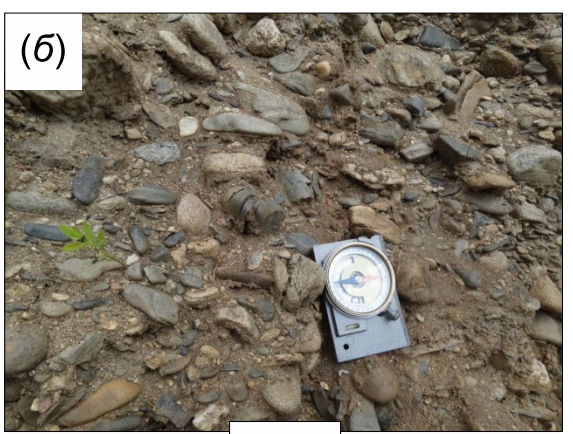

S1337
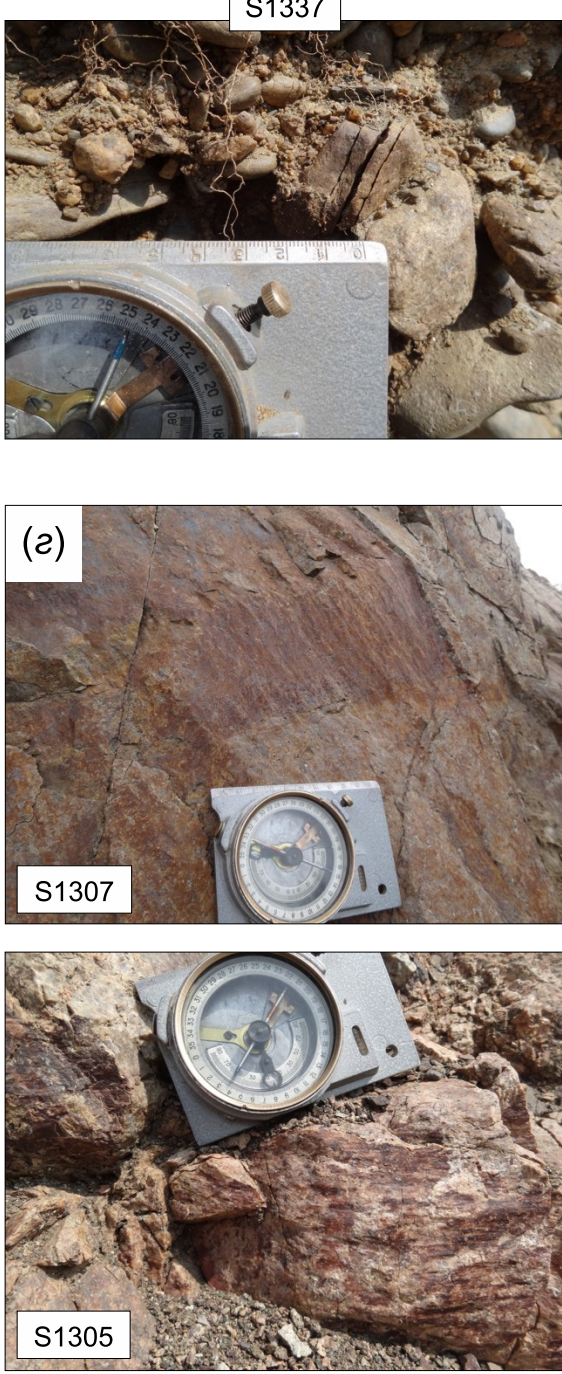

Рис. 2. Некоторые особенности трещинной структуры горных пород Западного Забайкалья (фотографии автора): (a) - трещины в мезозойских конгломератах; (б) - трещины в кайнозойских галечниках; (в) - низкотемпературная минерализация на поверхностях трещин; (2) - штрихи скольжения. Цифрами с буквой S обозначены номера точек наблюдения на рисунке 1.

Fig. 2. Features of the fractured rock structure of West Transbaikalia (the photo by the author): (a) - fractures in Mesozoic conglomerates; (б) - fractures in Cenozoic gravel; ( 8 ) - low-temperature mineralization on the fracture surfaces; (2) slickensides. The numbers with letter S correspond to the numbers of the observation points in Fig. 1.

ния. В связи с этим далее анализировались два основных направления разрывов, для которых проверялось соответствие локальных решений эталонным парагенезам разломов соответствующих кинематических типов.
Всего установлено четыре структурных парагенеза (ПГ) надлокального уровня с разным количеством локальных решений (рис. 4, в). Это сброс ПГ-І (восемь решений) и взброс ПГ-II (пять решений) с простиранием $55^{\circ}$, а также левосторонний сдвиг 


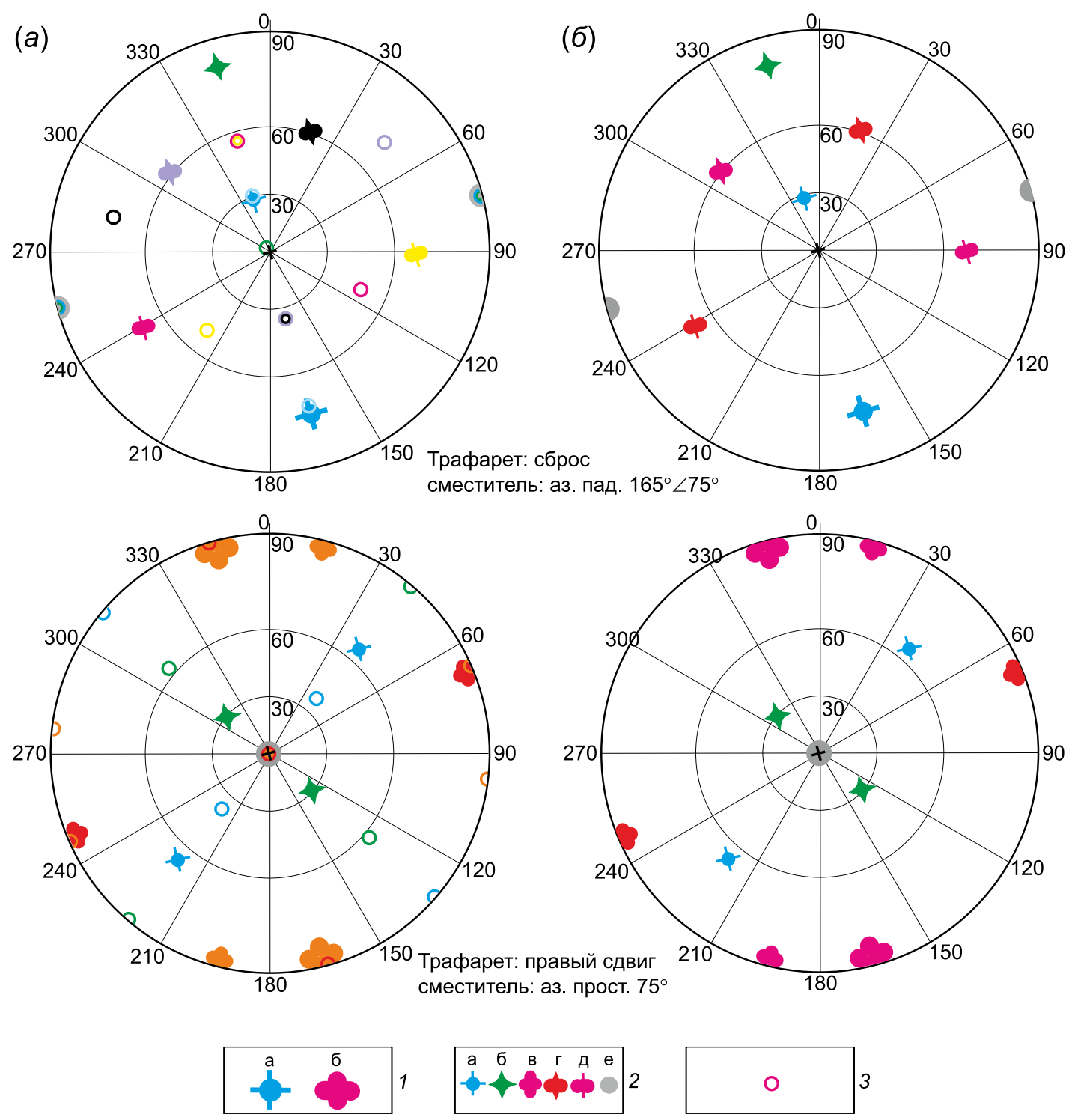

Рис. 3. Трафареты парагенезов разрывных дислокаций в зонах локальных разломов (a) и в разломных зонах более высокого иерархического уровня (б) по [Seminsky, 2015], использованные в данной работе.

1 - полюсы основного сместителя (разлома первого порядка): а - сброса, б - правостороннего сдвига; 2 - полюсы разрывов второго порядка разных типов: а - сброса, б - взброса, в - сдвига, г - сбросо-сдвига, д - взбросо-сдвига, е - трансформационного типа; 3 - полюсы второстепенной и дополнительной систем трещин. Одинаковым цветом на рисунке $(a)$ показаны системы, образующие тройственный парагенез; на рисунке (б) - имеющие одинаковый кинематический тип (левосторонний сдвиг - красный, правосторонний сдвиг - малиновый).

Fig. 3. Templates of fracture parageneses for local fault zones $(a)$ and the fault zones of the higher hierarchical level (б) (from [Seminsky, 2015]), which were used in our study.

1 - poles of the main fault planes (faults of the $1^{\text {st }}$ order): a - normal fault, 6 - right-lateral strike-slip fault; 2 - poles of fractures of the $2^{\text {nd }}$ order , varying in types: a - normal, 6 - reverse, в - strike-slip, $\Gamma$ - strike-slip with normal component, д - strike-slip with reverse component, e - transform type; 3 - poles of the secondary and additional systems of fractures. In figure $(a)$, the systems comprising a triple paragenesis are shown in the same colour. Colour codes in figure (б): red - left-lateral normal fault, crimson - right-lateral normal fault.

ПГ-III (пять решений) и сброс ПГ-IV (два решения) с ориентировкой $80^{\circ}$.

ПГ-І - это совокупность разрывов зоны сброса. Он выделяется не только общим количеством решений, но и преобладанием именно сбросов (четыpe решения), соответствующих магистральному сместителю разлома северо-восточного простира- ния, поэтому парагенез сбросовой зоны в первую очередь рассмотрен на следующем этапе порангового анализа в качестве основного кинематического типа Чикой-Ингодинского разлома (рис. 4, г). Следующим по количеству локальных решений является взброс (ПГ-II) с простиранием 55․ Этот парагенез также характеризуется значительным ко- 


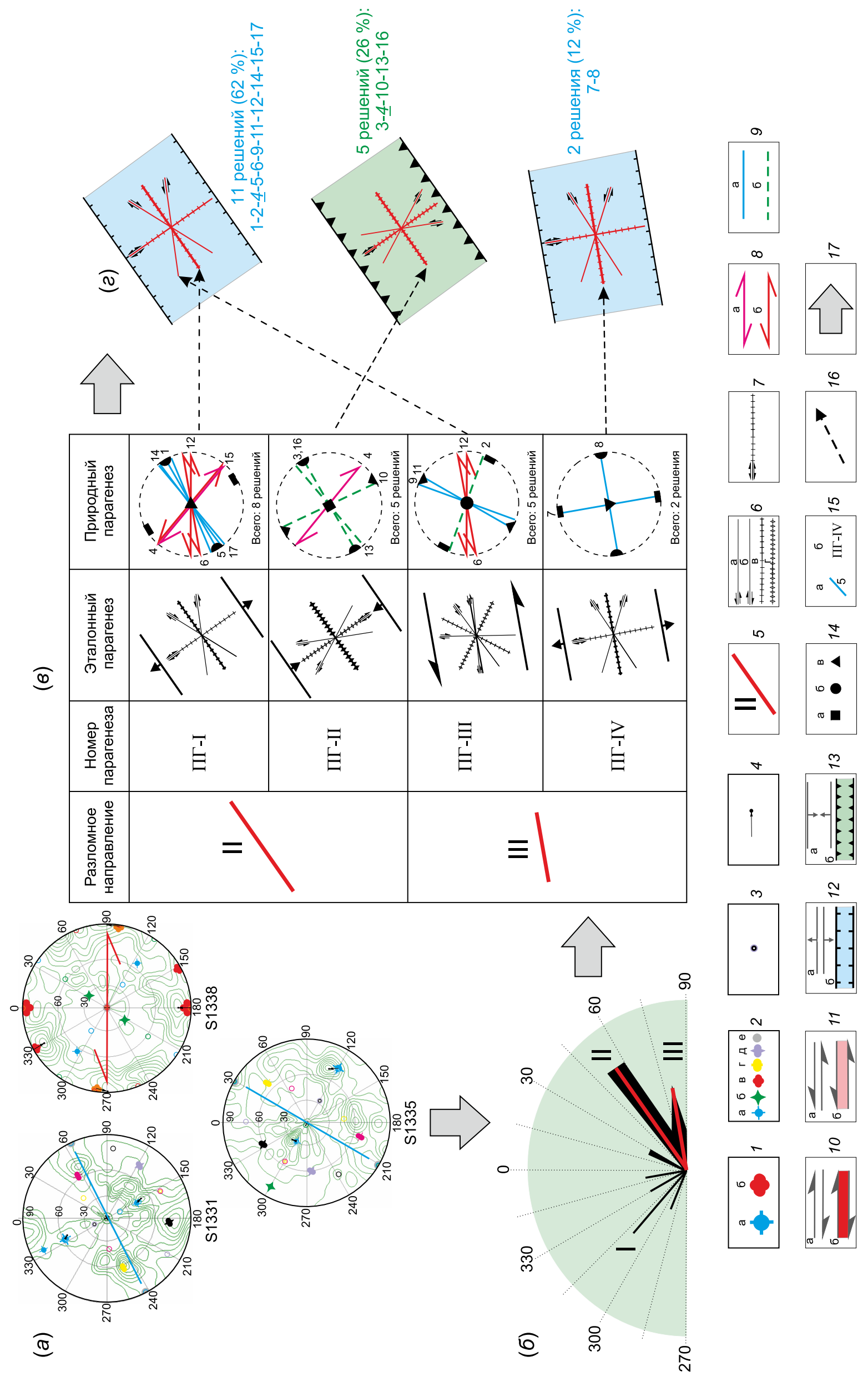


Рис. 4. Схема реализации порангового структурно-парагенетического анализа разрывов на примере зоны ЧикойИнгодинского разлома. (a) - трещиноватость в точках наблюдений (диаграммы построены в проекции верхней полусферы и совмещены с эталонными парагенезами разрывов и трещиноватости горных пород [Burzunova, 2011, 2017]) и ориентировка реконструированных зон скалывания: сбросов и сдвига с левосторонним смещением крыльев; (б) - роза-диаграмма азимутов простирания локальных зон скалывания; (в) - результаты парагенетического анализа разрывных структур 2-го порядка (надлокального уровня) для статистически значимых направлений простирания разломов; (2) - парагенезы разрывных структур регионального уровня.

1 - полюсы основного сместителя локального уровня (разрыв первого порядка): а - сброса, б - левостороннего сдвига; 2 - полюсы разрывов второго порядка разных типов: а - сброса, б - взброса, в - сдвига, г - сбросо-сдвига, д - взбросо-сдвига, е - трансформационного типа; 3 - полюсы второстепенной и дополнительной систем трещин; 4 - черной точкой показано положение полюса максимума сферограммы, соответствующего положению основных разрывов на эталонных трафаретах (начало стрелки); 5 - разломное направление, установленное при построении роза-диаграммы; 6 - система разрывных структур второго порядка с левосдвиговым (а), правосдвиговым (б), сбросовым (в) или взбросовым (г) характером перемещения крыльев; 7 - система разрывных структур второго порядка, характеризующихся одинаковой пространственной ориентировкой, но отличающихся характером перемещения крыльев (сброс, левый или правый сдвиги); 8-9 - локальные разрывы (зоны скалывания): 8 - с горизонтальным перемещением крыльев (а - правый сдвиг, б - левый сдвиг), 9 - с перемещением крыльев в вертикальной плоскости (а - сброс, б - взброс); 10-13 - зона скалывания первого порядка, развитие которой на надлокальном (а) или региональном (б) уровне структурообразования приводит к правому сдвигу (10), левому сдвигу (11), растяжению (12) или сжатию

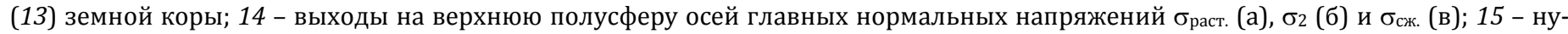
мерация решений о локальных разрывах (а) и парагенеза разрывных структур надлокального уровня (б); 16 - стрелки, отображающие связь природного парагенезиса надлокального уровня с разрывами зон скалывания регионального уровня иерархии; 17 - стрелки, позволяющие проследить отдельные этапы анализа. Курсивом и нижним подчеркиванием обозначены номера локальных решений, удовлетворяющих нескольким парагенезам регионального уровня.

Fig. 4. The scheme of the structural-paragenetic analysis of faults by ranks (case of the Chikoi-Ingoda fault zone). (a) - fractures at the observation points (the diagrams were constructed in the projection of the upper hemisphere and compared with the reference sets of rock fractures [Burzunova, 2011, 2017]), and the orientations of the reconstructed cleavage zones: normal faults and the strike-slip fault (left-lateral displacement of the fault wings); (б) - rose-diagram of the azimuths of local cleavage zones; $(\theta)$ - results of the paragenetic analysis of the $2^{\text {nd }}$ order fractures (supra-local level) for statistically significant fault strikes; (2) - parageneses of regional faults.

1 - poles of the main local fault planes ( $1^{\text {st }}$ order): a - normal, 6 - left-lateral strike-slip; 2 - poles of the $2^{\text {nd }}$ order fractures varying in types: a - normal, $\sigma$ - reverse, в - strike-slip, $\Gamma$ - strike-slip with normal component, $д$ - strike-slip with reverse component, e - transform type; 3 - poles of the secondary and additional fracture systems; 4 (black dot) - position of the pole of the maximum in the spherical diagram corresponding to the position of the main faults in the reference templates (arrow start point); 5 - fault direction revealed by the rose-diagrams; 6 - system of the $2^{\text {nd }}$ order fractures: (a) - left-lateral strike-slip, (б) - right-lateral strike-slip, (в) - normal, (Г) - reverse; 7 - system of $2^{\text {nd }}$ order fractures with similar orientations but different displacement of the wings (normal, left- or right-lateral strikeslip); 8-9 - local fractures (cleavage zones): 8 - horizontal displacement of the wings (a - right-lateral strike-slip, 6 - left-lateral strike-

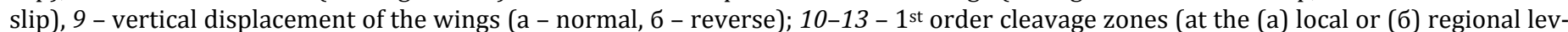
els, their development leads to (10) right-lateral strike-slip, (11) left-lateral strike-slip, (12) extension, and (13) compression of the crust;

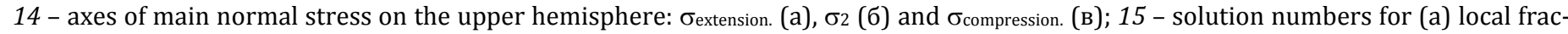
tures and (б) fracture parageneses of the supra-local level; 16 - arrows showing the relationships between the natural paragenesis of the supra-local level and the fractures in the cleavage zones of the regional hierarchic level; 17 - arrows tracing the stages of the analysis. Italics and underscored numbers refer to the local solutions acceptable for several regional parageneses.

личеством решений, соответствующих магистральному сместителю - три локальных взброса северовосточной ориентировки. Динамическая обстановка, при которой сформировались локальные разрывы ПГ-II, кардинально отличается от рассмотренной выше, поэтому на региональном уровне мы должны рассмотреть этот взброс как одну из обстановок формирования разрывов зоны ЧикойИнгодинского дизъюнктива (рис. 4,2 ).

Далее по количеству решений следует ПГ-III левосторонний сдвиг с простиранием 80. Этот разлом, вероятно, сформировался в условиях северо-западно-юго-восточного растяжения земной коры, в зоне регионального сброса (рис. 4, 2). Таким образом, самостоятельный кинематический тип разлома регионального уровня не выделяется.

Последний парагенез - сброс с простиранием $80^{\circ}$ (ПГ-IV). Возможно, эта обстановка связана с локальной вариацией простирания регионального разлома, так как оба решения зафиксированы в одной точке наблюдения (локальном объеме горных пород). Однако простирание сброса здесь отличается от наиболее проявленного (СВ 55) направления на $25^{\circ}$, что предполагает формальное выделение еще одной обстановки регионального уровня.

В целом, разлом, проходящий по юго-восточному склону Малханского хребта, имеет генеральное 
простирание $55^{\circ}$ и на разных тектонических этапах испытывал как сбросовые, так и взбросовые перемещения крыльев. Элементами зоны регионального сброса являются собственно сбросы (ПГ-І) и субширотные левосторонние сдвиги (ПГ-III). Соответственно и все локальные решения ПГ-I и ПГ-III должны быть отнесены к региональной зоне. Следует отметить, что в зоне регионального сброса установлены различные локальные решения. Например, решение 2 соответствует локальному взбросу с простиранием $290^{\circ}$, однако, по результатам порангового структурно-парагенетического анализа, оно принадлежит левостороннему сдвигу надлокального уровня в зоне регионального разлома сбросового кинематического типа (см. рис. 4). Парагенетические ассоциации разрывов зоны сброса объединяют бо́льшую часть решений, таких как сбросы северо-восточной ориентировки, субширотные левосторонние сдвиги, северо-западные сдвиги трансформационного типа и взброс с западсеверо-западным простиранием.

Выявленный природный парагенез взбросовой зоны включает взбросы северо-восточной и северо-западной ориентировки, а также северо-западный сдвиг с правосторонним перемещением крыльев. Сдвиговое решение 4 удовлетворяет парагенезу сброса и взброса (см. рис. 4, в, 2), так как является разрывом, ортогональным простиранию зоны дизъюнктива. Вероятно, зона Чикой-Ингодинского разлома претерпела два тектонических этапа с северо-западно-юго-восточной ориентировкой главной оси - растяжение и сжатие. При этом локаль- ные решения, удовлетворяющие зоне сброса, преобладают - 62 \% против 26 \% (см. рис. 4, г).

Ранее в горном обрамлении юго-восточного борта Чикойской впадины вкрест простирания ЧикойИнгодинского разлома согласно карте [Khrenov, 1988] произведены геолого-структурные наблюдения на девяти обнажениях (рис. 5). По результатам структурно-парагенетического анализа отмечается проявление правосторонних сдвигов северо-восточного простирания за пределами впадины, а юговосточный борт депрессии ограничен сбросами такой же ориентировки [Cheremnykh, 2012]. Широкое развитие правосторонних сдвигов в юго-восточном обрамлении Чикойской впадины может быть связано как со сдвиговым характером Монголо-Охотского структурного шва (при этом впадина формируется как присдвиговый грабен), так и с возможным отражением более раннего сдвигового этапа развития региона, реликты которого наблюдаются за пределами современной Чикой-Ингодинской разломной зоны. Согласно карте разломов юга Восточной Сибири [Khrenov, 1988], правосторонние сдвиговые перемещения крыльев в зоне Чикой-Ингодинского дизъюнктива имеют раннепалеозойский возраст. Однако геоэлектрический разрез земной коры, построенный по данным магнитотеллурического зондирования, свидетельствует о том, что современное положение изучаемого нами сегмента Чикой-Ингодинской разломной зоны зафиксировано в районе впадины [Seminsky et al., 2013]. В этом случае к юго-востоку от Чикойской впадины действительно могут наблюдаться про-

Рис. 5. Схема распространения откартированных разрывов в пределах изученных сегментов разломных зон Западного Забайкалья.

1 - элементы залегания разрывов, установленных на первом этапе структурно-парагенетическогоанализа: правый сдвиг (а), левый сдвиг (б), взброс (в), сброс (г); 2 - участки распространения однотипных разрывов близкой пространственной ориентировки; 3 - осевые линии: а - крупных разломов, б - вероятное положение секущего разлома сдвигового типа; 4 - эпицентры и механизмы очагов землетрясений [Melnikova et al., 2016, 2017]: стереограммы построены в проекции нижней полусферы (выходы главных осей сжатия и растяжения указаны соответственно черными и белыми точками), цифрами указана дата события; 58 - некоторые особенности геологической структуры согласно [Naletov, 1959, 1963; Shcheglov, 1961; Starchenko, 1962; Florensov, 1964]: 5 - разломы: а - достоверные, предполагаемые и перекрытые осадками, б - зоны тектонитов (катаклаза, рассланцевания, милонитизации); 6 - разновозрастные магматические образования и домезозойские метаморфические породы; 7 - мезозойские отложения; 8 - кайнозойские отложения. На врезке приведены фотографии некоторых откартированных разрывных нарушений. Цифры в квадратах соответствуют местоположению разрывов на схеме.

Fig. 5. Schematic map showing the faults in the studied segments of the fault zones in West Transbaikalia.

1 - details of the fractures detected at the first stage of the structural-paragenetic analysis: right-lateral strike-slip (a), left-lateral strikeslip (б), reverse (в), normal (г); 2 - sites with fractures of the same types with similar spatial orientation; 3 - axial lines: a - large faults, 6 - probable position of the transcurrent strike-slip fault; 4 - epicenters and mechanisms of earthquake foci [Melnikova et al., 2016, 2017]: the stereograms are constructed in the projection of the lower hemisphere (the main compression and extension axes are marked by black and white dots, respectively); the numbers show the dates of the events; 5-8 - features of the geological structure [Naletov, 1959, 1963; Shcheglov, 1961; Starchenko, 1962; Florensov, 1964]: 5 - faults: a - observed, assumed, and covered by sediments, б - zones of tectonites (cataclase, schistosity, mylonitization); 6 - hererochronous mafic formations and pre-Mesozoic metamorphic rocks; 7 - Mesozoic deposits; 8 - Cenozoic deposits. Inset - photos of mapped fractures. Boxed numbers refer to the locations of the faults and fractures in the schematic map. 


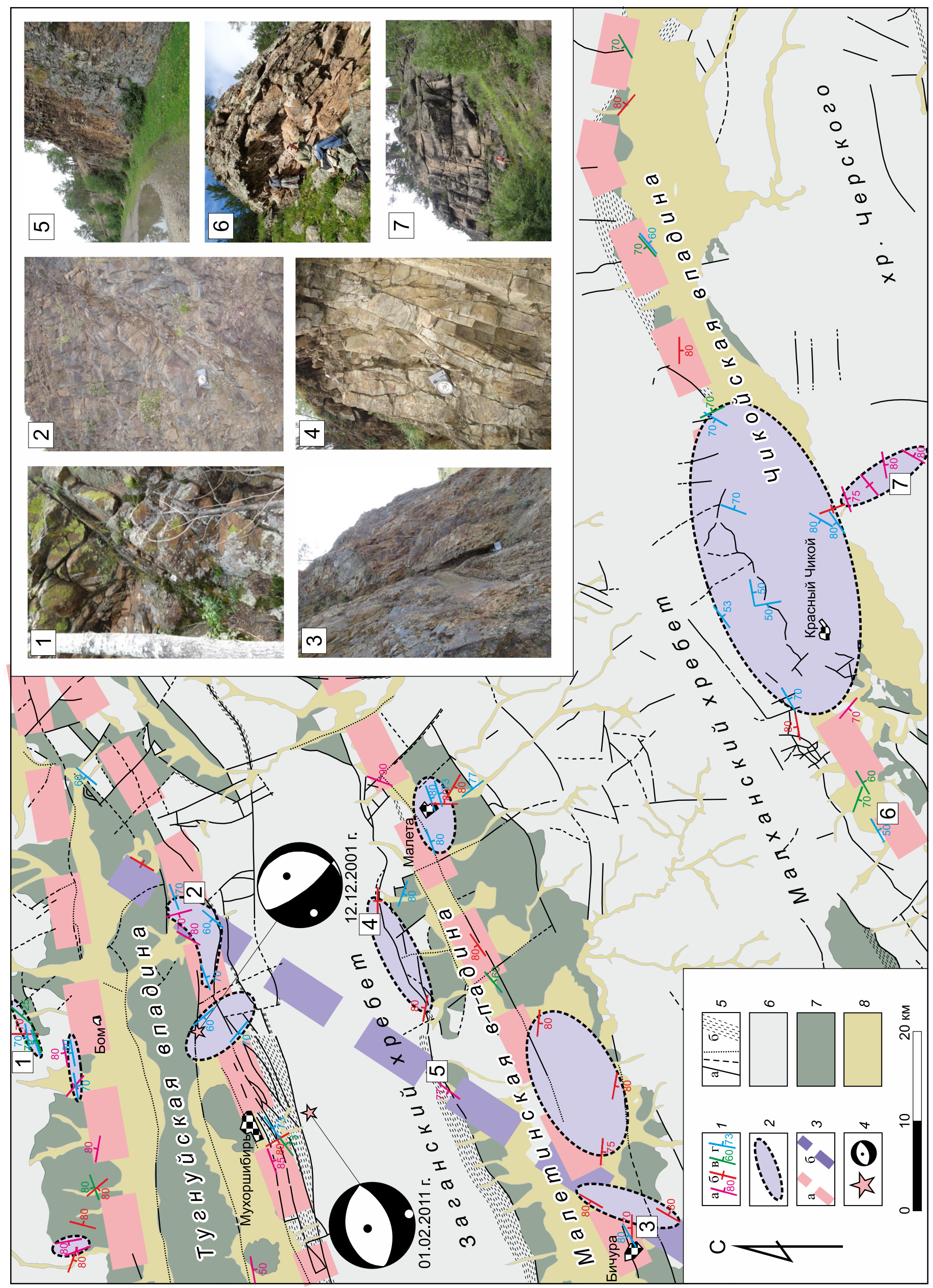


явления более ранних этапов разломообразования. Подобная ситуация, только с левосторонними сдвиговыми смещениями на периферии разломных зон, выявлена ранее на территории Прибайкалья [Cheremnykh, 2010].

Хилокская разломная зона изучена на протяжении 70 км. Наблюдения проведены в районе Малетинской впадины (см. рис. 1). На примере этого разлома рассмотрим специфику порангового анализа дизъюнктивных дислокаций - этапы II.3 и II.4 согласно [Seminsky, 2015]. Одной из его составляющих является анализ площадного распространения разрывов (см. рис. 5).

Во всех изученных разломных зонах наблюдаются скопления однотипных разрывов (одного кинематического типа и близкого простирания) в смежных точках наблюдения. Так, в пределах изученного сегмента Хилокского дизъюнктива (район Малетинской впадины) зафиксированы следующие поля (с юго-запада на северо-восток): левосторонних сдвигов север-северо-восточной ориентировки, субширотных левых сдвигов (два участка), сбросов северо-восточного простирания (см. рис. 5). Размеры участков распространения однотипных разрывов составляют километры и даже десятки километров, поэтому их следует отнести к более высокому рангу структур, по сравнению с локальным. К последнему мы причисляем решения, полученные для обнажений горных пород в точках наблюдения. Нет сомнения в том, что неравномерное распределение точек геолого-структурных наблюдений в пределах изученных разломных зон не позволяет установить и проследить всю совокупность разрывов надлокального уровня. Кроме того, внутренняя структура зоны разлома состоит не только из однотипных дислокаций. Разломная зона - совокупность различно ориентированных и разнотипных разрывов. Также в пределах района исследований разрывы имеют различный возраст образования или активизации, что необходимо учитывать в ходе порангового структурно-парагенетического анализа.

Так, на рисунке 6 показан анализ 20 локальных решений о типе разрывов в зоне Хилокского дизъюнктива. На роза-диаграмме обособились четыре основных направления разрывов (рис. $6, a$ ), для которых установлены пять парагенезов (рис. 6, б). При этом три из пяти парагенезов нами уже отмечены выше при анализе распределения локальных решений по площади. Для каждого из пяти парагенезов переходного ранга выявлена вероятная совокупность локальных решений. Парагенезу сброса (ПГ-V) удовлетворяют двенадцать решений, субширотному сдвигу с левосторонним перемещением крыльев (ПГ-I) - девять решений, левостороннему сдвигу с простиранием $30^{\circ}$ и правостороннему сдвигу с простиранием $50^{\circ}-$ по три решения. Одно решение - взброс с простиранием $50^{\circ}$.

При переходе на региональный уровень первым следует рассмотреть парагенез с наибольшим количеством локальных решений - сброс. Элементами этого парагенеза, помимо собственно сбросов (ПГ-V), являются широко распространенные в пределах изученного сегмента разлома левосторонние сдвиги субширотной ориентировки (ПГ-I) и правосторонние сдвиги север-северо-восточного простирания (ПГ-IV). Выше отмечено, что если надлокальные разрывы соответствуют парагенезу зоны регионального разлома, то и локальные решения этих парагенезов должны быть отнесены к региональной зоне. Таким образом, большинство реконструкций (82 \%) соответствует парагенезу регионального сброса с простиранием $70^{\circ}$ (рис. 6 , в).

Следующей по количеству локальных решений динамической обстановкой, не удовлетворяющей зоне сброса северо-восточной ориентировки, является левосторонний сдвиг (ПГ-II). Ему соответствуют три решения, одно из которых - сброс с аз. прост. $323^{\circ}$. Этот локальный сброс удовлетворяет двум парагенезам: сбросу восток-северо-восточной ориентировки и север-северо-восточному сдвигу, что учитывалось при подсчете процентов. Таким образом, региональному сдвигу с простиранием $30^{\circ}$ отвечает $13 \%$ решений.

Лишь одно решение является взбросом с аз. пад. $140 \angle 60^{\circ}$, что составляет $5 \%$ от общего числа локальных зон скалывания. Оно зафиксировано в мезозойских породах центральной части Малетинской впадины (см. рис. 5) и должно рассматриваться как еще одна динамическая обстановка регионального уровня.

Для Северо-Тугнуйского разлома исследован 33-километровый сегмент. Наблюдения произведены в магматических и вулканогенно-осадочных породах мезозойского возраста. Получено 16 локальных решений о зонах скалывания (см. рис. 5), на примере которых рассмотрим особенности двух вариантов структурно-парагенетического анализа (рис. 7): 1) способа, охарактеризованного выше, на примере Чикой-Ингодинской и Хилокской разломных зон и 2) методики использования стереографических проекций, основным преимуществом которых является одновременное отображение азимутов и углов падения локальных разрывов.

По результатам построения роза-диаграммы для изученного сегмента разломной зоны установлено одно направление регионального дизъюнктива $80^{\circ}$ (рис. $7, a$ ). Этому направлению соответствуют парагенезы сброса (44 \% решений), взброса (34 \%) и сдвига с правосторонним перемещением крыльев (22\%). Проведение анализа с использованием 
(a)

0 330 30

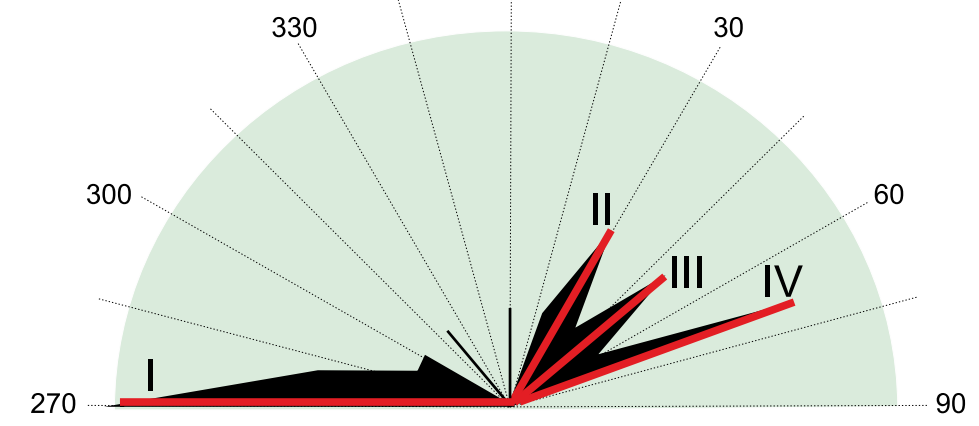

(б)

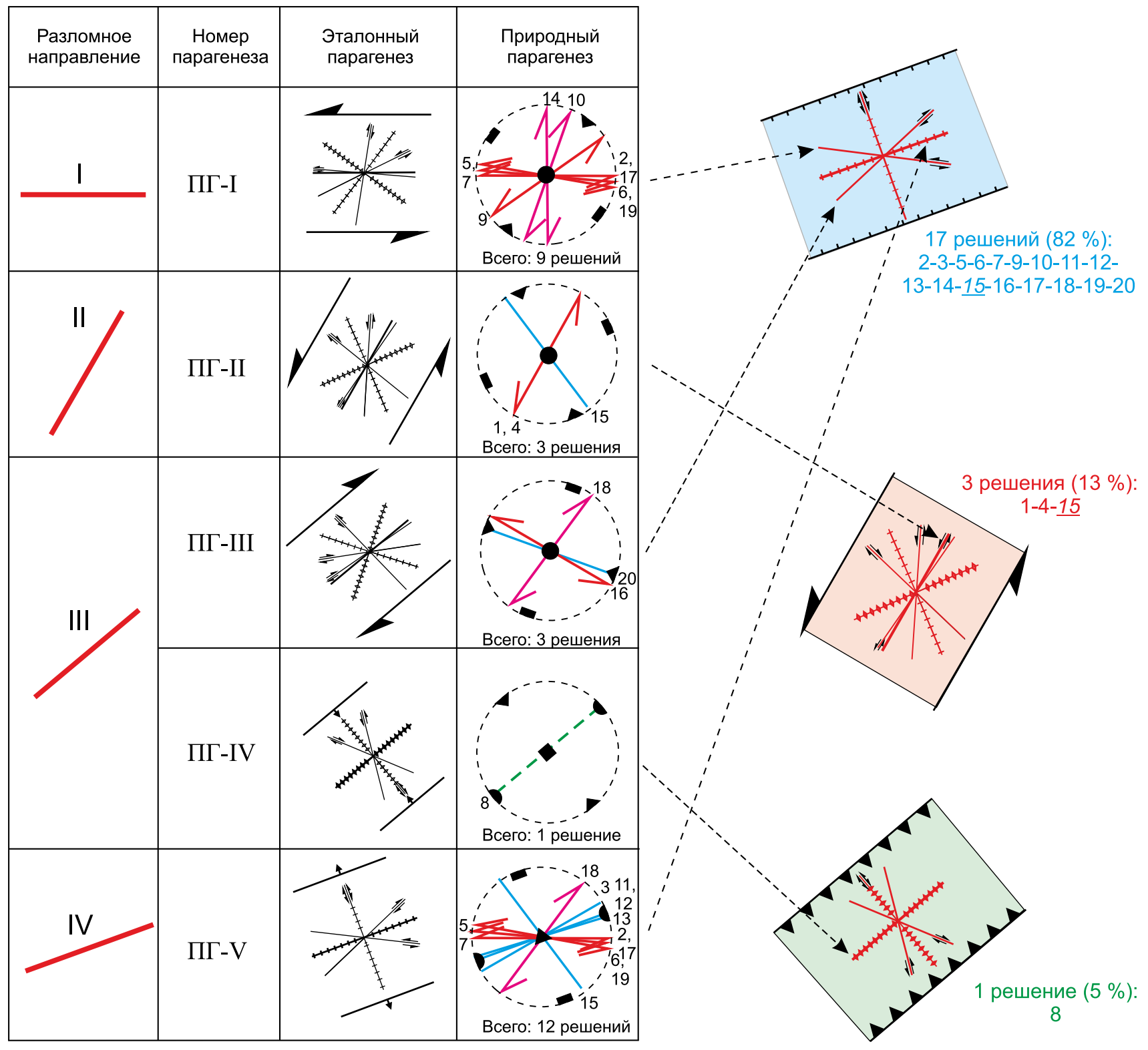

Рис. 6. Результаты рангового парагенетического анализа разрывных структур зоны Хилокского разлома. (a) - розадиаграмма направлений реконструированных зон скалывания - локальных разрывов; (б) - результаты парагенетического анализа разрывных структур надлокального уровня для статистически значимых разломных направлений; (в) - парагенезы разрывных структур регионального уровня. Условные обозначения см. на рис. 4.

Fig. 6. Paragenetic rank analysis results for the fractures of the Khilok fault. $(a)$ - rose-diagram for the reconstructed cleavage zones (local fractures); (б) - results of the paragenetic analysis of the supra-local fractures for statistically significant fault directions; $(8)$ - parageneses of regional fractures. See the legend in Fig. 4. 
(б)

(a)

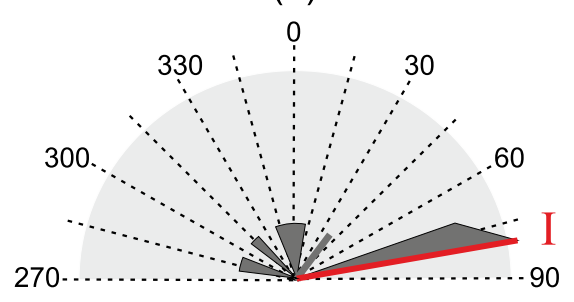

9 решений (44 \%): 1-2-3-5-9-11-12-14-15

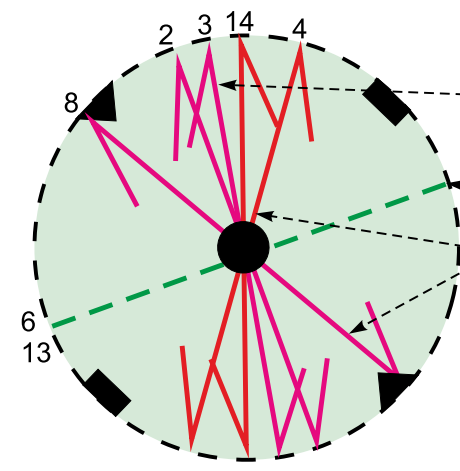

7 решений (34 \%): 2-ㅗ-3-6-8-13-14

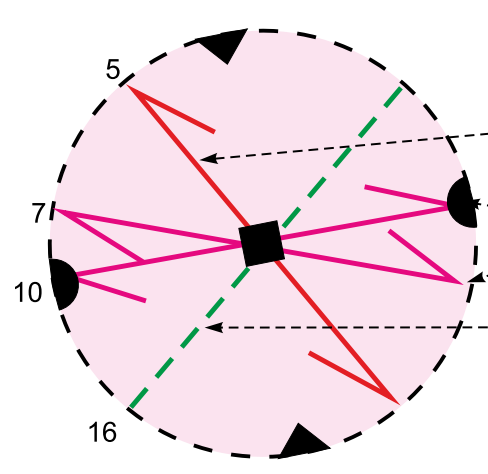

4 решения (22\%): $\underline{5}-7-10-16$
(8)

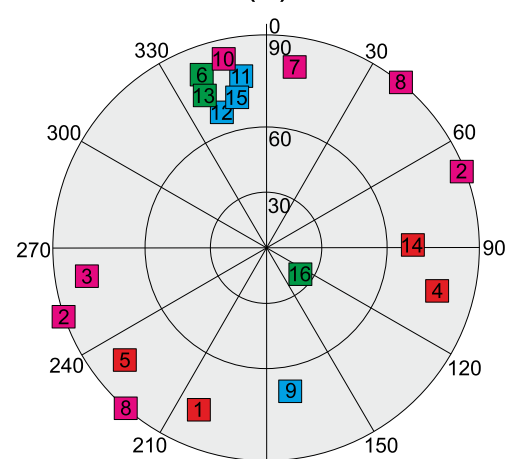

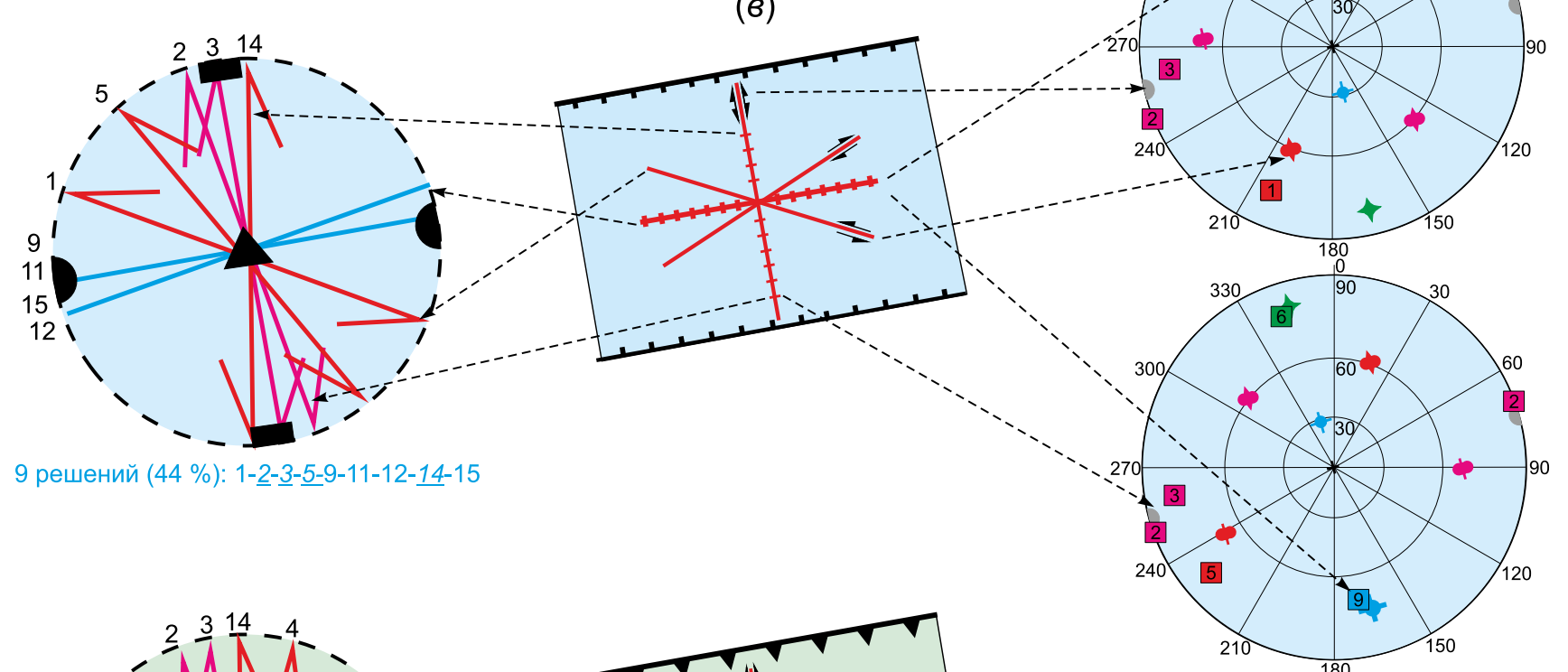

9 решений $(44 \%): 18$ - 2 - $\underline{3}-\underline{5}-\underline{6}-9-11-12-15$

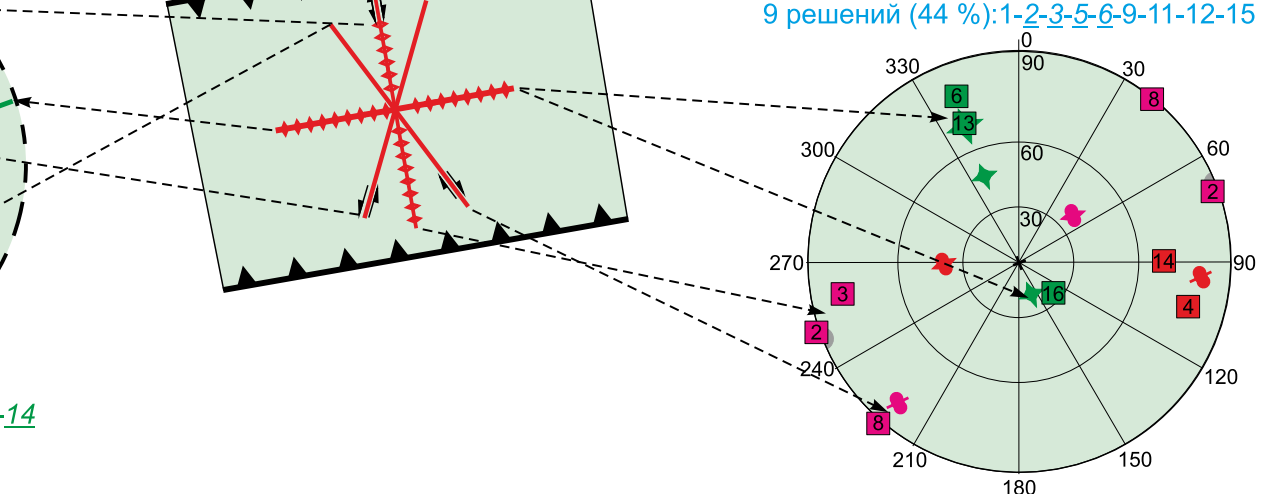

8 решений (37 \%): 2 - $\underline{3}-4-\underline{6}-8-13-14-\underline{16}$

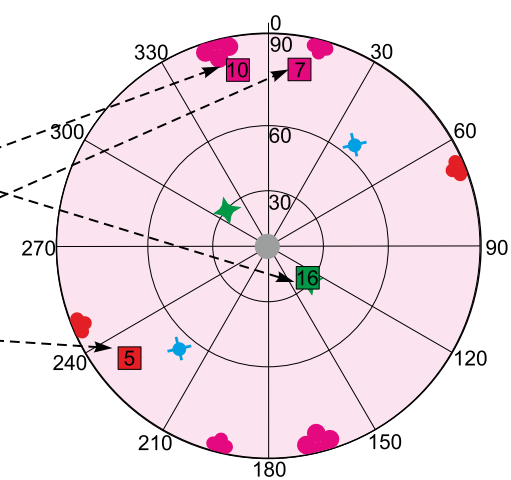

4 решения (19\%): $\underline{5}-7-10-\underline{16}$ 
Рис. 7. Результаты парагенетического анализа разрывных структур зоны Северо-Тугнуйского разлома. (a) - розадиаграмма направлений разрывов и результаты анализа; (б) - сферограмма (верхняя полусфера), на которую вынесены полюсы 16 локальных разрывов и результаты ее сопоставления с эталонными диаграммами разломов (трафаретами); (в) - парагенезы разрывных структур регионального уровня. Условные обозначения см. на рис. 4 , пояснения в тексте.

Fig. 7. Paragenetic analysis results for the fractures of the North Tugnui fault. $(a)$ - rose-diagram for the fractures, and the analysis results; (б) - spherogram (upper hemisphere) showing the poles of 16 local fractures, and the results of its comparison with the reference fault templates; $(\theta)$ - parageneses of regional fractures. See the legend in Fig. 4 . Explanations in the text.

стереографических проекций (рис. 7, б) позволило получить такой же основной результат (рис. 7, в), однако в ходе анализа проявились некоторые различия.

Отображение локальных разрывов на стереографических проекциях позволяет применить для проведения анализа трафареты с бо́льшим количеством разрывов второго порядка. Кроме того, на трафаретах учитывается не простирание разрывов, а азимут и угол их падения, что увеличивает достоверность результатов структурно-парагенетического анализа.

Вначале поранговый анализ был проведен для зоны сброса (рис. 7, в), в связи с преобладанием локальных разрывов этого типа. Так, для регионального сброса восток-северо-восточного простирания характерны сбросы надлокального уровня как с падением на север-северо-восток, так и с падением в противоположном направлении (рис. 7, б). Парагенезы этих разломов включают левосторонние сдвиги (локальные решения 1 и 5), а также разрывы трансформационного типа (решения 2 и 3). Кроме того, в парагенезе зоны сброса с аз. пад. $170 \angle 70^{\circ}$ присутствует крутопадающий взброс с аз. пад. $340 \angle 80^{\circ}$ (решение 6). С другой стороны, к парагенезам сбросовых зон не отнесен меридиональный левосторонний сдвиг (решение 14). Простирание этого разрыва почти перпендикулярно (отклоняется всего на $10^{\circ}$ ) основному разломному направлению, что позволило отнести его к парагенезу сбросовой зоны в первом варианте анализа. Однако при рассмотрении элементов залегания данного разрыва на стереографических проекциях, где учитывается угол падения плоскости сместителя, установлено значительное отклонение положения его полюса от идеализированных трафаретов сбросов. Этот локальный разрыв более вероятен для зоны регионального взброса, который рассмотрен ниже.

К парагенезу зоны взброса восток-северо-восточного простирания, помимо собственно взбросов, крутопадающих на север-северо-восток, и сдвигов различного простирания (решения 2-4, 8 и 14), отнесен надвиг с аз. пад. $130 \angle 25^{\circ}$ (решение 16).
В рассмотренном выше «плоском» варианте анализа он не соответствовал парагенезу взброса из-за существенного (на $40^{\circ}$ ) отклонения простирания. Однако для пологих плоскостей вариации элементов залегания в азимутальной плоскости менее существенны, чем изменения углов наклона. Этот разрыв отчетливо (по азимуту и углу) соответствует парагенезу зоны правостороннего сдвига восток-северо-восточной ориентировки (рис. 7, б). Ему удовлетворяют два сдвига с правосторонним перемещением крыльев (решения 7 и 10), левосторонний сдвиг (решение 5) и охарактеризованный выше надвиг (решение 16).

Выше уже отмечено, что отличия, проявившиеся при реализации парагенетического анализа разрывов в разных вариантах, не повлияли на его основной результат. В изученном сегменте зоны СевероТугнуйского разлома выявлено три парагенеза регионального уровня - сброс, взброс и сдвиг с правосторонним перемещением крыльев, имеющие восток-северо-восточное простирание - 80, 70 и 80 соответственно (рис. 7, в). В зонах восток-северовосточных сбросов и взбросов широко развиты лево- и правосторонние сдвиги север-северо-западного простирания, которые относятся к трансформационному типу. Этим объясняется достаточно частое повторение локальных разрывов (пять из шестнадцати решений) в парагенезах разломных зон различного кинематического типа (рис. $7, a$, б).

Северо-Заганский дизъюнктив изучен на протяжении 58 км по простиранию. Наблюдения произведены в 13 точках (см. рис. 1). Поранговый анализ 14 локальных решений (см. рис. 5), проведенный с использованием стереографических проекций, позволил установить, что этот региональный разлом, вероятнее всего, является сбросом северовосточного простирания (около 67 \% локальных решений). Кроме того, реконструированы парагенезы субширотного правостороннего сдвига и взброса северо-восточной ориентировки - 24 и $9 \%$ от общего количества решений соответственно.

В зоне влияния рассматриваемого разлома в 2001 и 2011 гг. произошли сейсмические события, 
для которых реконструированы фокальные механизмы [Melnikova et al., 2016, 2017]. Механизмы очагов землетрясений сбросовые, но отличаются ориентировкой нодальных плоскостей и, соответственно, простиранием субгоризонтальных осей растяжения (см. рис. 5). Так, при ощутимом землетрясении 2011 г. ( $\left.\mathrm{M}_{\mathrm{w}}=4.7\right)$ активизировались разломы восток-северо-восточного простирания. Это генеральное направление Северо-Заганского разлома, который, согласно реконструкциям, является сбросом. Очаг более раннего землетрясения (2001 г.) также является сбросом, но с простиранием нодальных плоскостей в северо-западных румбах. Наличие сбросов, ортогональных основному разлому, не является неожиданным, так как структурный парагенез крупной разломной зоны состоит из нескольких элементов - разломов низшего уровня: продольного и поперечного сбросов, а также сдвигов, ориентированных под углами к основному сместителю. Нами в пределах зоны СевероЗаганского разлома, кроме сбросов северо-восточного простирания (пять решений с азимутом простирания 40-70), реконструированы два локальных сброса с азимутами простирания 310 и $320^{\circ}$. Эти разрывы зафиксированы в кристаллических горных породах (т.н. S1309), а также в мезозойских отложениях и в кайнозойских осадках (т.н. S1308), что свидетельствует об относительно молодом возрасте сбросов.

Таким образом, для четырех крупных разломов района исследования изучены разноранговые парагенезы разрывов и выявлены региональные динамические обстановки, которые не могут существовать одновременно и соответственно относятся к разным этапам тектогенеза. Возрастные взаимоотношения выявленных обстановок рассматриваются в следующем разделе статьи.

\section{4. ОБСУЖДЕНИЕ ПОЛУЧЕННЫХ РЕЗУЛЬТАТОВ}

Проведенное исследование показало, что все многообразие локальных разрывов соответствует двум (в зонах Чикой-Ингодинского и Хилокского разломов) или трем (в зонах Северо-Тугнуйского и Северо-Заганского дизъюнктивов) динамическим обстановкам регионального уровня. Относительно более молодой, как правило, является динамическая обстановка, в которой формировался парагенез, наиболее часто встречающийся и выраженный большим количеством установленных разнотипных структурных элементов [Seminsky, 2014]. Изученные разломные зоны Западного Забайкалья преимущественно формировались в условиях растяжения с северо-западным простиранием оси, так как структурные парагенезы сбросов подтвержда- ются 44-82 \% локальных решений о зонах скалывания различных типов (сбросов, сдвигов и даже взбросов), а также характеризуются большим количеством разнотипных разломов надлокального уровня (см. рис. 4, 6 и 7). Парагенезы зон взброса и сдвига охватывают значительно меньшее число локальных разрывов: 5-37 \% и 19-24 \% соответственно. Выше отмечено, что наблюдения проведены в породах различного возраста, поэтому рассмотрим парагенезы, выявленные в мезозойских отложениях и кайнозойских осадках.

Для Чикойской впадины получены следующие решения. В отложениях мезозойского возраста реконструированы два локальных разрыва: сброс (решение 9) и левосторонний сдвиг (решение 15). Эти решения удовлетворяют парагенезу регионального сброса северо-восточного простирания (см. рис. 4,2 ). Для кайнозойских осадков получено семь решений о локальных зонах скалывания: сбросы северо-восточного простирания (три решения), субширотные левосторонние сдвиги (два решения), а также северо-восточный и северо-западный взбросы (два решения).

Локальные сбросы и левосторонние сдвиги (пять решений), установленные в вулканогенноосадочных отложениях мезозойского возраста Малетинской впадины, являются элементами парагенеза сброса, и лишь одно решение отвечает зоне северо-восточного взброса. В кайнозойских осадках реконструированы левосторонние сдвиги субширотной ориентировки, характерные для зон сбросов, а также север-северо-восточный сдвиг с левосторонним перемещением крыльев.

В отложениях мезозоя Тугнуйской впадины локальные решения (два решения) укладываются в парагенезы сбросов северо-восточного простирания. Из четырех решений, установленных в кайнозойских осадках депрессии, два соответствуют парагенезу зоны сброса (сброс и правый сдвиг), одно является правым сдвигом с аз. пад. $160 \angle 70^{\circ}$ и одно - левосторонним сдвигом с простиранием 30. Последний подобен сдвигу в кайнозойских осадках Малетинской впадины. Кроме того, серия право- и левосторонних сдвигов такой же ориентировки в окрестностях Тугнуйской и Малетинской впадин образует линейную структуру север-северо-восточного простирания шириной в несколько километров (см. рис. 5).

Таким образом, парагенезы разрывов в мезозойских и кайнозойских отложениях Западного Забайкалья соответствуют реконструкциям, охарактеризованным выше при анализе всех решений по каждому из изученных разломов. Преобладает количество локальных решений, характерное для продольных по отношению ко впадинам зон региональных сбросов. Существенно меньше в мезозой- 
ских и кайнозойских породах реконструировано локальных взбросов. При этом взбросы мезозойских отложений тяготеют к центральным частям впадин (Тугнуйская и Малетинская депрессии), а дислокации подобного кинематического типа в кайнозойских осадках (северо-западный борт Чикойской впадины) - к краям депрессии.

Взбросы, зафиксированные в мезозойских и более ранних отложениях, закономерны, так как известны проявления регионального сжатия в пределах Западного Забайкалья в юрское время [Pavlov, 1979], а образования структур сжатия в породах кайнозоя не типичны. Однако для кайнозойских пород выявлено всего два взброса с падением в сторону склонов - $65^{\circ} \angle 70^{\circ}$ и $320^{\circ} \angle 70^{\circ}$. Они реконструированы в пределах Чикойской впадины, в тех же точках наблюдения, что и крутопадающие сбросы и, как показано выше, могут являться элементами парагенеза последних. Падение плоскостей взбросов в склон также может быть связано с ростом поднятия. Кроме того, имеется вероятность формирования разрывов в рыхлых отложениях у подножия Малханского хребта в результате склоновых процессов.

В целом, значительное преобладание в породах разного возраста разрывов, характерных для парагенезов разломных зон сбросового кинематического типа, и известные механизмы очагов землетрясений района свидетельствуют о том, что наиболее молодой тектонический этап в Западном Забайкалье характеризуется растяжением земной коры в направлении северо-запад - юго-восток.

\section{5. ЗАКЛЮЧЕНИЕ}

На основе структурно-парагенетического анализа разрывов, впервые проведенного для Западного Забайкалья методом спецкартирования, охарактеризованы парагенезы разноранговых дизъюнктивов Северо-Тугнуйской, Северо-Заганской, Хилокской и Чикой-Ингодинской разломных зон. Статистический характер исходного фактического материала позволил определить степень распространенности каждого парагенеза регионального уровня и, таким образом, в первом приближении оценить его относительный возраст. В пределах региональных разломов наиболее часто встречаются парагенезы сбросов северо-восточной ориентировки, менее проявлены парагенезы взбросов и правосторонних сдвигов того же или близкого простирания. При этом элементами парагенезов сбросов надлокального и регионального уровня могут быть не только локальные сбросы, но и сдвиги, взбросы и надвиги. Таким образом, все многообразие локальных решений группируется в несколько парагене- зов надлокального уровня, которые являются элементами двух-трех парагенезов региональных разломов. Так, для Западного Забайкалья установлено два основных этапа формирования хрупких и квазихрупких деформаций в разломных зонах. Если исходить из предположения, что чаще встречаемые разрывы имеют более молодой возраст, то внутренняя структура зон изученных разломов формировалась в разное время в обстановках сначала сжатия, а затем растяжения с северо-западным простиранием соответствующих субгоризонтальных осей. Парагенезы правостороннего сдвига, выявленные в районе Тугнуйской впадины и к юго-востоку от Чикойской депрессии, тоже сформировались ранее этапа растяжения. Однако их возрастные взаимоотношения с этапом сжатия пока не ясны.

Откартирован диагональный по отношению ко впадинам левосторонний сдвиг с простиранием $30^{\circ}$ (см. рис. 5), который «накладывается» на зоны Хилокского и Северо-Заганского дизъюнктивов. Данная структура является не типичной для района исследований, а реконструкции этой динамической обстановки в кайнозойских осадках могут быть связаны с молодым возрастом образования разлома. В то же время данная сдвиговая зона с простиранием, отличающимся от ориентировки региональных разломов района, требует дальнейших исследований.

В ходе исследования, сделаны выводы относительно особенностей реализации порангового структурно-парагенетического анализа. Единообразие сбора фактического материала в породах разного возраста и состава, а также достаточно формализованная методика его обработки на разных этапах анализа позволяют количественно оценить вероятность реконструкций парагенезов каждого иерархического уровня. Для повышения точности результатов, при наличии данных об азимутах и углах падения сместителей разрывов, на каждом уровне иерархии анализ необходимо проводить с использованием стереографических проекций. В целом, методы и приемы структурнопарагенетического анализа разрывов и трещиноватости горных пород позволили получить новый материал о разнотипных и разноранговых разрывах в зонах крупных разломов Западного Забайкалья, территории менее активной в кайнозойское время по сравнению с Прибайкальем.

\section{6. БЛАГОДАРНОСТИ}

Автор благодарен сотрудникам Института земной коры CO РАН д.г.-м.н. К.Ж. Семинскому за ценные советы по обработке и анализу фактического материала, к.г.-м.н. А.А. Боброву, а также А.С. Че- 
ремных, Р.М. Зарипову, А.А. Решиловой и А.К. Семинскому за содействие в сборе полевых данных и Е.А. Маслову, И.К. Декабрёву за помощь в оформле- нии графики. Некоторые виды представленных исследований выполнены при поддержке РФФИ (проект № 16-05-00154).

\section{7. ЛИТЕРАTУРA / REFERENCES}

Arzhannikova A.V., Vassallo R., Arzhannikov S.G., Jolivet M., 2015. Morphotectonics and paleoseismology of the eastern end of the Bolnay fault (Mongolia). Russian Geology and Geophysics 56 (10), 1484-1490. https://doi.org/10.1016/ j.rgg.2015.09.010.

Burzunova Y.P., 2011. Angles between conjugated systems of near-fault fractures in idealized and natural paragenesises formed in various dynamic settings. Litosfera (Lithosphere) (2), 94-110 (in Russian) [Бурзунова Ю.П. Углы между сопряженными системами приразломных трещин в идеализированных и природных парагенезисах, формирующихся в различных динамических обстановках // Литосфера. 2011. № 2. С. 94-110].

Burzunova Y.P., 2017. Rock fractures near faults: specific features of structural-paragenetic analysis. Geodynamics \& Tectonophysics 8 (3), 673-693 (in Russian) [Бурзунова Ю.П. Трещины горных пород вблизи разломов: особенности применения структурно-парагенетического анализа // Геодинамика и тектонофизика. 2017. T. 8. № 3. C. 673-693]. https://doi.org/10.5800/GT-2017-8-3-0312.

Cheremnykh A.V., 2010. Internal structures of fault zones in the Priolkhonie and evolution of the state of stresses of the upper crust of the Baikal rift. Geodynamics \& Tectonophysics 1 (3), 273-284 (in Russian) [Черемных A.В. Внутренняя структура разломных зон Приольхонья и эволюция напряженного состояния верхней коры Байкальского рифта. Геодинамика и тектонофизика. 2010. Т. 1. № 3. C. 273-284]. https://doi.org/10.5800/GT2010-1-3-0021.

Cheremnykh A.V., 2012. The fault-block structure of the Southern East Siberia: the hierarchy of fractures, and the state of stress. In: Tectonophysics and Topical Issues of Earth Sciences. Abstracts of the All-Russia Conference. IPE RAS, Moscow, Vol. 1, p. 445-448 (in Russian) [Черемных A.В. Разломно-блоковая структура юга Восточной Сибири: иерархия дизъюнктивов и напряженное состояние // Тектонофизика и актуальные вопросы наук о Земле: тезисы докладов Всероссийской конференции. М.: ИФЗ РАН, 2012. Т. 1. С. 445-448].

Danilovich V.N., 1961. Method of Belts in Study of Fracturing Related to the Fault Displacements. Irkutsk Polytechnic Institute, Irkutsk, 47 p. (in Russian) [Данилович B.Н. Метод поясов в исследовании трещиноватости, связанной с разрывными смещениями. Иркутск: Иркутский политехнический институт, 1961. 47 с.].

Demin A.N., Fomin I.N., Khrenov P.M., Cherednichenko V.P., 1982. Kinematics of the Mongol-Okhotsk suture. In: V.A. Kuznetsov (Ed.), Rifts and endogenous mineralization of the Baikal-Amur region. Nauka, Moscow, p. 54-72 (in Russian) [Демин А.Н., Фомин И.Н., Хренов П.М., Чередниченко В.П. Кинематика Монголо-Охотского шва // Разломы и эндогенное оруденение Байкало-Амурского региона / Ред. В.А. Кузнецов. М.: Наука, 1982. C. 54-72].

Florensov N.A. (Ed.), 1964. Geological Map of the USSR. M-49-VII. West Transbaikalia Series. Scale 1:200000. Chita Geological Department (in Russian) [Геологическая карта СССР. M-49-VII. Серия Западно-Забайкальская. Масштаб 1:200000 / Ред. Н.А. Флоренсов. Читинское геологическое управление, 1964].

Gladkov A.S., Lunina O.V., 2004. Fractures in Late Cenozoic Sediments: New Possibilities for Structural Analysis. Doklady Earth Sciences 399 (8), 1071-1073.

Gzovsky M.V., 1975. Fundamentals of Tectonophysics. Nauka, Moscow, 536 p. (in Russian) [Гзовский М.В. Основы тектонофизики. М.: Наука, 1975. 536 с.].

Hancock P.L., 1985. Brittle microtectonics: principles and practice. Journal of Structural Geology 7 (3-4), 437-457. https://doi.org/10.1016/0191-8141(85)90048-3.

Jolivet M., Arzhannikov S., Chauvet A., Arzhannikova A., Vassallo R., Kulagina N., Akulova V., 2013. Accomodating largescale intracontinental extension and compression in a single stress-field: a key example from the Baikal Rift System. Gondwana Research 24 (3-4), 918-935. https://doi.org/10.1016/j.gr.2012.07.017.

Khrenov P.M. (Ed.), 1988. Fault Map of the Southern East Siberia. Scale 1:1500000. VSEGEI, Leningrad (in Russian) [Карта разломов юга Восточной Сибири. Масштаб 1:1500000 / Ред. П.М. Хренов. Л.: ВСЕГЕИ, 1988]

Lukianov A.V., 1965. Structural Features of Horizontal Movements of the Earth's Crust. Nauka, Moscow, 210 p. (in Russian) [Лукьянов А.В. Структурные проявления горизонтальных движений земной коры. М.: Наука, 1965. 210 c.].

Lunina O.V., 2016. The digital map of the Pliocene-Quaternary crustal faults in the southern East Siberia and the adjacent Northern Mongolia. Geodynamics \& Tectonophysics 7 (3), 407-434 (in Russian) [Лунина О.В. Цифровая карта разломов для плиоцен-четвертичного этапа развития земной коры юга Восточной Сибири и сопредельной территории Северной Монголии // Геодинамика и тектонофизика. 2016. Т. 7. № 3. С. 407-434]. https://doi.org/10.5800/GT-2016-7-3-0215.

Melnikova V.I., Seredkina A.I., Radziminovich Y.B., Melnikov A.I., Gilyova N.A., 2017. The February 1, 2011 Mw 4.7 earthquake: Evidence of local extension in Western Transbaikalia (Eastern Siberia). Journal of Asian Earth Sciences 135, 110-121. https://doi.org/10.1016/j.jseaes.2016.12.031. 
Melnikova V.I., Seredkina A.I., Radziminovich Y.B., Melnikov A.I., Gilyova N.A., Tubanov Ts.A., 2016. The Zagan earthquake of February 1, 2011, in the low-seismoactive zone of Western Transbaikalia: observations and analysis. Seismic Instruments 52 (4), 290-300. https://doi.org/10.3103/S0747923916040058.

Naletov P.I. (Ed.), 1959. Geological Map of the USSR. M-48-II. West Transbaikalia Series. Scale 1:200000. Irkutsk Geological Department (in Russian) [Геологическая карта CССР. M-48-II. Западно-Забайкальская серия. Масштаб 1:200000 / Ред. П.И. Налетов. Иркутское геологическое управление, 1959].

Naletov P.I. (Ed.), 1963. Geological Map of the USSR. M-48-XVIII. West Transbaikalia Series. Scale 1:200000. Buryatian Geological Department (in Russian) [Геологическая карта CCCP. M-48-XVIII. Западно-Забайкальская серия. Масштаб 1:200000 / Ред. П.И. Налетов. Бурятское геологическое управление, 1963].

Parfenov V.D., 1984. To the technique of tectonophysical analysis of geological structures. Geotectonics (1), 60-72 (in Russian] [Парфенов В.Д. К методике тектонофизического анализа геологических структур // Геотектоника. 1984. № 1. С. 60-72].

Pavlov S.F. (Ed.), 1979. The Ratio of the Ancient and Cenozoic Structures in the Baikal Rift Zone. Siberian Branch, Nauka, Novosibirsk, 125 p. (in Russian) [Соотношение древней и кайнозойской структур в Байкальской рифтовой зоне / Ред. С.Ф. Павлов. Новосибирск: Наука. СО, 1979. 125 с.].

Radziminovich Y.B., 2014. The earthquake of October 9, 1864 in Western Transbaikalia. Journal of Volcanology and Seismology 8 (5), 314-321. https://doi.org/10.1134/S0742046314050078.

Rastsvetaev L.M., 1982. Structural drawings of fractures and their geomechanical interpretation. Doklady AN SSSR 267 (4), 904-909 (in Russian) [Расцветаев Л.М. Структурные рисунки трещиноватости и их геомеханическая интерпретация // Доклады АН СССР. 1982. Т. 267. № 4. С. 904-909].

Seminsky K.Zh., 2003. The Internal Structure of Continental Fault Zones. Tectonophysical Aspect. Publishing House of SB RAS, Geo Branch, Novosibirsk, 242 p. (in Russian) [Семинский К.Ж. Внутренняя структура континентальных разломных зон. Тектонофизический аспект. Новосибирск: Издательство СО РАН, филиал «Гео», 2003. 242 c.].

Seminsky K.Zh., 2014. Specialized mapping of crustal fault zones. Part 1: Basic theoretical concepts and principles. Geodynamics \& Tectonophysics 5 (2), 445-467 (in Russian) [Семинский К.Ж. Спецкартирование разломных зон земной коры. Статья 1: Теоретические основы и принципы // Геодинамика и тектонофизика. 2014. Т. 5. № 2. C. 445-467]. https://doi.org/10.5800/GT-2014-5-2-0136.

Seminsky K.Zh., 2015. Specialized mapping of crustal fault zones. Part 2: Main stages and prospects. Geodynamics \& Tectonophysics 6 (1), 1-43 (in Russian) [Семинский К.Ж. Спецкартирование разломных зон земной коры. Статья 2: Основные этапы и перспективы // Геодинамика и тектонофизика. 2015. Т. 6. № 1. С. 1-43]. https://doi.org/10.5800/GT-2015-6-1-0170.

Seminsky K.Zh., Cheremnykh A.V., 2011. Jointing patterns and stress tensors in Cenozoic sediments of the Baikal rift: development of the structural-genetic approach. Russian Geology and Geophysics 52 (3), 353-367. https:// doi.org/10.1016/j.rgg.2011.02.008.

Seminsky K.Zh., Kozhevnikov N.O., Cheremnykh A.V., Pospeeva E.V., Bobrov A.A., Olenchenko V.V., Tugarina M.A., Potapov V.V., Zaripov R.M., Cheremnykh A.S., 2013. Interblock zones in the crust of the southern regions of East Siberia: tectonophysical interpretation of geological and geophysical data. Geodynamics \& Tectonophysics 4 (3), 203-278. [Ceминский К.Ж., Кожевников Н.О., Черемных А.В., Поспеева Е.В., Бобров А.А., Оленченко В.В., Тугарина М.А., Потапов B.B., Зарипов Р.М., Черемных А.С. Межблоковые зоны в земной коре юга Восточной Сибири: тектонофизическая интерпретация геолого-геофизических данных // Геодинамика и тектонофизика. 2013. Т. 4. № 3. C. 203-278]. https://doi.org/10.5800/GT-2013-4-3-0099.

Shcheglov A.D. (Ed.), 1961. Geological Map of the USSR. M-49-XIV. East Transbaikalia Series. Scale 1:200000. Chita Geological Department (in Russian) [Геологическая карта CCCP. M-49-XIV. Серия Восточно-Забайкальская Масштаб 1:200000 / Ред. А.Д. Щеглов. Читинское геологическое управление, 1961].

Sherman S.I., 1977. Physical Regularities of Faulting in the Earth's Crust. Siberian Branch, Nauka, Novosibirsk, 102 p. (in Russian) [Шерман С.И. Физические закономерности развития разломов земной коры. Новосибирск: Наука. CO, 1977. 102 с.].

Sherman S.I., Pleshanov S.P., 1980. The method of belts in the studies of near-fault fracturing. In: Geology, Prospecting and Exploration of Mineral Ore Deposits. Irkutsk Polytechnical Institute, Irkutsk, p. 8-20 (in Russian) [Шерман С.И., Плешанов С.П. Метод поясов в исследовании приразломной трещиноватости // Геология, поиски и разведка месторождений рудных полезных ископаемых. Иркутск: Иркутский политехнический институт, 1980. C. 8-20].

Smekalin O.P., Chipizubov A.V., Imayev V.S., 2010. Paleoearthquakes in the Pribaikalie: methods and results of dating. Geodynamics \& Tectonophysics 1 (1), 55-74 (in Russian) [Смекалин О.П., Чипизубов А.В., Имаев В.С. Палеоземлетрясения Прибайкалья: методы и результаты датирования // Геодинамика и тектонофизика. 2010. Т. 1. № 1. C. 55-74]. https://doi.org/10.5800/GT-2010-1-1-0006.

Starchenko V.V. (Ed.), 1962. Geological Map of the USSR. M-49-XIII. East Transbaikalia Series. Scale 1:200000. Chita Geological Department (in Russian) [Геологическая карта СССР. M-49-XIII. Серия Восточно-Забайкальская Масштаб 1:200000 / Ред. В.В. Старченко. Читинское геологическое управление, 1962].

Stoyanov S.S., 1977. Mechanism of Formation of Fault Zones. Nedra, Moscow, 144 p. (in Russian) [Стоянов C.C. Mеханизм формирования разрывных зон. М.: Недра, 1977. 144 с.]. 
A.V. Cheremnykh: Parageneses of fractures in large fault zones...

Volkov V.V. (Ed.), 1978. Tectonic Faults of Transbaikalia. Nauka, Novosibirsk, 112 p. (in Russian) [Тектонические разломы Забайкалья / Ред. В.В. Волков. Новосибирск: Наука, 1978. 112 с.]

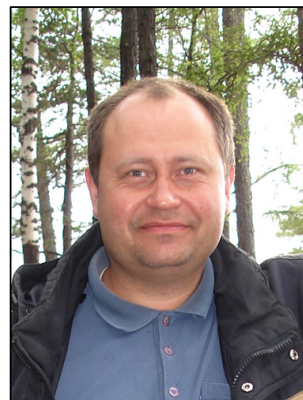

Александр Викторович Черемных, канд. геол.-мин. наук, с. н. с.

Институт земной коры СО РАН

664033, Иркутск, ул. Лермонтова, 128, Россия

e-mail: cherem@crust.irk.ru

ORCID ID https://orcid.org/0000-0001-6239-1412

Alexander V. Cheremnykh, Candidate of Geology and Mineralogy, Senior Researcher Institute of the Earth's Crust, Siberian Branch of RAS

128 Lermontov street, Irkutsk 664033, Russia 